\title{
8
}
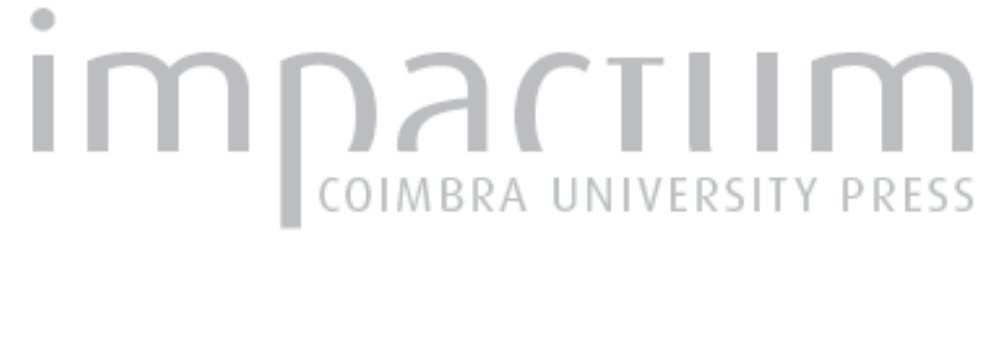

\section{Doutoramento em Geografia Física dedicado aos riscos geomorfológicos}

Autor(es): Rebelo, Fernando

Publicado por: Associação Portuguesa de Riscos, Prevenção e Segurança

URL persistente:

URI:http://hdl.handle.net/10316.2/40137

DOI:

DOI:https://doi.org/10.14195/1647-7723_5_6

Accessed : $\quad$ 26-Apr-2023 16:24:27

A navegação consulta e descarregamento dos títulos inseridos nas Bibliotecas Digitais UC Digitalis, UC Pombalina e UC Impactum, pressupõem a aceitação plena e sem reservas dos Termos e Condições de Uso destas Bibliotecas Digitais, disponíveis em https://digitalis.uc.pt/pt-pt/termos.

Conforme exposto nos referidos Termos e Condições de Uso, o descarregamento de títulos de acesso restrito requer uma licença válida de autorização devendo o utilizador aceder ao(s) documento(s) a partir de um endereço de IP da instituição detentora da supramencionada licença.

Ao utilizador é apenas permitido o descarregamento para uso pessoal, pelo que o emprego do(s) título(s) descarregado(s) para outro fim, designadamente comercial, carece de autorização do respetivo autor ou editor da obra.

Na medida em que todas as obras da UC Digitalis se encontram protegidas pelo Código do Direito de Autor e Direitos Conexos e demais legislação aplicável, toda a cópia, parcial ou total, deste documento, nos casos em que é legalmente admitida, deverá conter ou fazer-se acompanhar por este aviso.

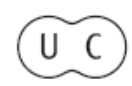




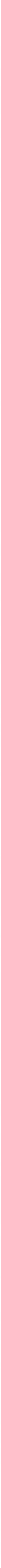




\section{Doutoramento em Geografia Física dedicado aos riscos geomorfológicos}

\section{Fernando Rebelo}

No dia 27 de Janeiro de 1998, realizou-se, em Lisboa, aquele que pode considerar-se o primeiro Doutoramento em Geografia Física dedicado aos estudos de riscos naturais no nosso país.

Movimentos de Vertente e Perigosidade Geomorfológica na Região a Norte de Lisboa é o título da tese apresentada por José Luís Zêzere para o seu Doutoramento pela Universidade de Lisboa. Na sua forma actual, policopiada, apresenta 575 páginas, muitas delas ilustradas com belas fotografias e bons mapas a cores, e ainda 3 mapas geomorfológicos de pormenor, extra-texto. Trata-se de um trabalho particularmente bem estruturado, iniciando-se com uma pequena "Introdução" (6 páginas) e terminando com um "Resumo e principais conclusões" (12 páginas). Pelo meio ficam dez capítulos - "O quadro geomorfológico" "Classificação e características dos movimentos de vertente", "Metodologia e técnicas de estudo", "Tipologia e dinâmica dos movimentos de vertente na região a Norte de Lisboa: exemplificação monográfica", "Papel da erosão lateral dos cursos de água e das acções antrópicas na actividade dos movimentos de vertente na região a Norte de Lisboa", "A avaliação da estabilidade das vertentes e a determinação dos parâmetros físicos dos terrenos por análise inversa", "Análise estatística dos movimentos de vertente nas áreas-amostra", "Estudo comparativo da tipologia, morfometria e factores condicionantes dos movimentos de vertente nas áreas-amostra", "A precipitação como factor desencadeante dos movimentos de vertente" e, finalmente, "A avaliação da perigosidade geomorfológica". Depois das conclusões segue-se uma "Bibliografia" muito completa, em especial no que respeita a movimentos de vertente.

Torna-se clara a opção de J.L. ZÊZERE pela palavra inglesa "hazard", que traduziu, à semelhança de espanhóis e italianos por "perigosidade". Sendo o "risco" o somatóriode "hazard" (o "aléas" dos franceses) com "vulnerabilidade", verifica-se que o Autor não quereria introduzir o homem e as suas realizações no trabalho que elaborou. Todavia, num espaço como o que escolheu, tal era completamente impossível deslizamentos de variados tipos, desabamentos equedas de blocos, estudados como "crises" ou, melhor, como "manifestações da crise"(1), afectaram directa ou indirectamente o Homem, como o próprio Autor mostra em fotografias ou cartogramas de pormenor. Por outro lado, terá sido, por vezes, o próprio homem o factor essencial no desencadear de algumas dessas "crises".

O estudo é, portanto, bem mais do que o seu título anuncia. Trata de "hazards", claro, mas baseia-se muito em análise de casos concretos de manifestações de risco e não lhe teria ficado mal assumi-lo no título do trabalho, mesmo que tal implicasse, em consciência, aprofundar um pouco mais a parte final.

Todo o espaço estudado é, infelizmente para os habitantes, muito rico em riscos geomorfológicos e o Autor mostra-o claramente. Além disso, os mapas geomorfológicos de pormenor das áreas-amostra (Calhandriz, Lousa, Pinheiro de Loures, Fanhões e Trancão) são de uma riqueza notável mostrando a hidrografia, a litologia do substracto, a estrutura e as formas ligadas à estrutura, as formas e as formações fluviais, as formas e as formações de vertente e interflúvio, as formas ligadas à actividade humana e, naturalmente, numa tese como esta, a dinâmica das vertentes com uma distinção importante quanto ao grau de actividade dos fenómenos identificados activos, dormentes e estabilizados.

Com o presente trabalho de J. L. ZÊZERE, a bibliografia sobre riscos, em geral, e sobre riscos geomorfológicos, em particular, começa também a ganhar importância no nosso país; aguarda-se, por isso, com muito interesse, a sua rápida publicação.

(1)L. FAUGÈrRES (1990), "La dimension des faits et la théorie du risque". Le Risque et la Crise”, Malta, Foundation for International Studies, 1990, p. $31-60$.

\section{Livros recentes sobre a problemática dos riscos e das crises}

\section{Fernando Rebelo}

1. Com uma primeira edição datada de 1993, mas jáesgotada, L'Homme et l'Environnement, de YVETTE VEYRET e PIERRE PECH (Paris, PUF, Collection Premier Cycle, 1997, 2e édition corrigée, 423 p.) veio de novo para os escaparates das livrarias no passado mês de Julho de 1997.
Depois de uma Introdução naturalmente dedicada à evolução das relações entre o homem e o ambiente e de uma primeira parte dedicada aos recursos, renováveis e não renováveis, os riscos aparecem em força na segunda e na terceira partes (respectivamente, "Contraintes et risques: risques naturels, risques 